\title{
Planning and proportions in the domed octagonal churches of Late Antiquity
}

Mark J. Johnson

\section{(2) OpenEdition \\ 1 Journals}

Electronic version

URL: http://journals.openedition.org/edl/1145

DOI: 10.4000/edl.1145

ISSN: 2296-5084

Publisher

Université de Lausanne

\section{Printed version}

Date of publication: 15 May 2018

Number of pages: $145-166$

ISBN: 978-2-940331-68-0

ISSN: 0014-2026

Electronic reference

Mark J. Johnson, "Planning and proportions in the domed octagonal churches of Late Antiquity », Études de lettres [Online], 2 | 2018, Online since 15 May 2020, connection on 11 December 2020. URL http://journals.openedition.org/edl/1145; DOI : https://doi.org/10.4000/edl.1145 


\section{PLANNING AND PROPORTIONS IN THE DOMED OCTAGONAL CHURCHES OF LATE ANTIQUITY}

An examination of basic principles in the design of domed octagonal churches from the period, show the prevalent use of round numbers divisible by ten in the measurements of the diameters of such churches. A second finding is that simple proportional schemes were used in the dimensions of the ground plans and vertical elements of these buildings. Particular reference is given to the churches of SS. Sergius and Bacchus in Istanbul and San Vitale in Ravenna.

The study of the architecture of the dome in Late Antiquity has largely centered on questions of structural design, materials, and construction technique. The actual planning of domes in the design process in terms of size and proportions and the laying out the design at the beginning of construction have been addressed only in a limited fashion ${ }^{1}$. These are issues raised in my study of the octagonal churches of Late Antiquity and which have wide implications for the practice of architectural design in late Roman and early Byzantine architecture ${ }^{2}$. This paper will focus on a few examples of domed octagonal churches in order to illustrate these underlying principles and lead to a greater understanding of the design of two churches in particular, the church of San Vitale in Ravenna and its closest relative, Sts. Sergius and Bacchus in Constantinople (modern Istanbul).

I. See, for example J. J. Rasch, “Zur Konstruktion spätantiker Kuppeln vom 3. bis 6. Jahrhundert".

2. M. J. Johnson, San Vitale in Ravenna and octagonal churches in Late Antiquity. 
The process of designing and laying out a design to begin construction, though often overlooked, is easy to grasp from a number of sources. A few concepts are crucial to understanding any architectural design and building process. The first is that of measurement. Builders in the fourth to sixth century used two types of feet as standard measurements, known today as the Roman and the Byzantine foot, with some variations in the exact metric equivalent ${ }^{3}$. The Roman foot (hereafter RF), roughly 29-30 cm, was used throughout the Roman period up until the early sixth century. It was replaced by the Byzantine foot (hereafter BF), roughly $31-32 \mathrm{~cm}$, beginning in the second decade of the sixth century. Throughout both periods builders would from time to time employ a substitute unit of measurement, the cubit, equal to $1 \frac{1 / 2}{2}$ feet.

A second important point is that in designing buildings, Roman, and later Byzantine, architects showed a marked preference for using round numbers divisible by 10 in major measurements, especially exterior lengths, widths, and in the case of rotundas, diameters. This is what Mark Wilson Jones called the "critical measurement", noting that units of feet or cubits of 50,100, and 150, were especially popular in Roman architectural design ${ }^{4}$. In his study of central plan Roman buildings, he observed that if the design of the building emphasized its exterior, then it was often the outer dimensions that would use such round numbers. So, for example, the Mausoleum of Augustus was laid out in a circle $300 \mathrm{RF}$ in diameter. If the building's design focused on its interior, then the main interior dimensions would usually be in round numbers. This is seen in the interior diameter of the fourth-century Mausoleum of Constantina (Santa Costanza) in Rome, of 75 RF or 50 cubits. In another observation with important implications for the design of the octagonal churches, Jones noted that some centrally-planned buildings have more than one ring and that both the inner and outer rings with their architectural features could be set out using critical measurements of round numbers and "be simply related to each other" ${ }^{5}$. In other

3. E. Shilbach, Byzantinische Metrologie, p. 13-16; M. W. Jones, Principles of Roman architecture, p. 74.

4. M. W. Jones, Principles of Roman architecture, p. 117; P. Underwood, "Some principles of measure in the architecture of the period of Justinian", passim.

5. M. W. Jones, "Principles of design in Roman architecture", p. 114. 
words, simple proportion schemes were used relating the outer circle or octagon to the inner one such as $2: 1,3: 2$ or $5: 3$.

Since our focus is on octagonal churches, it is important to note how an octagon might be laid out on paper or the ground. In preparing a site for the construction of an octagonal building, techniques and tools close to those used in land surveying were employed. The plan of the building would be marked on the ground using a schonion - a rope of thick hemp - and a measuring rod. The center point of the octagon, and therefore of the building itself, would be determined and marked with a stake. One end of the schonion would be attached to the stake and then pulled around it with the desired radius marked on the ground to draw a circle. Since most are based on diameters of 40,50, 60, or 80 feet then the knowledge of the lengths of the sides of the octagon would have been easily learned and listed on a chart. The side of an octagon 60 feet in diameter, for example, is 23 feet long. Therefore, the simplest method for laying out an octagon would be to draw a circle of the desired diameter and then mark eight equidistant points which become the corners of the octagon.

The critical measurement of an octagonal building is its diameter, or in the case of the double shell octagons employed in most of the churches under consideration here, the diameters of the both the inner and outer octagons, and in some churches, of the three octagons forming the basic design. Here an important clarification needs to be made. In previous scholarship on these buildings a diameter is often cited in the discussion, but it is not always clear which diameter is meant. Sometimes it is apparent that a person is actually referring to the width of an octagon as measured between facing sides. This measurement, however, is always going to be shorter than the diameter of the octagon when the angles are included, but in these cases, too, it is not always clear if a writer is referring to the diameter as measured from the inner side of the corners or their outer side, which would include the wall or stylobate of the octagon in question.

Returning to the process of laying out an octagonal structure, the next point is determining what the builder did after having set out the eight corners and sides of the octagon. Did he put the stylobate or wall on the outside of his marks, so that the marks determined the inner diameter of the octagon? Or did he place his structure on the inside of the marks, so that they had determined the outer diameter? Or, in 
laying out a ground floor inner octagon that was going to be composed of piers and/or columns, did he use the marks to determine the placement of the center of the stylobate and its columns and piers? It turns out that all three methods were used to some degree. However, outer octagons in double shell designs were almost always placed inside the circle defining the diameter, which is to say the diameter is measured from exterior corner to exterior corner. Most inner octagons were laid out in the same way, inside the circle circumscribing the stylobate. In a few cases, especially when large piers are being used to carry the weight of a masonry dome, the round number diameter of the inner octagon marks the center of its stylobate or its piers.

The reason that the outer dimension is the key one in the design of an octagonal structure becomes obvious upon reflection. On the one hand, the architect or builder does have to consider the interior span that will be covered by a dome or roof. This is not, however, the only consideration, as that roof is likely going to be supported by a drum or short wall and the thickness of that support must be taken into consideration. The inner diameter measurement gives no indication of the thickness of the wall supporting the covering. The outer diameter measurement, or at times a measurement to the center of the piers or columns of the inner octagon, does account for it.

In studying the octagonal churches, determining the diameter of the circles used in the layout of the octagonal churches meant first discovering the unit of measurement employed. This is done by checking not only the larger measurements of inner and outer corners of the octagon, but as many measurements of architectural features, such as the width of door and window openings, as possible. Whether or not a Roman or a Byzantine foot was used and which variant within those groups becomes clear after a number of such measurements are taken and converted. For example, if a room is $8.88 \mathrm{~m}$ wide, that measurement is exactly $30 \mathrm{RF}$ wide, using $0.296 \mathrm{~m}=1$ foot, but $27 \mathrm{3} / \mathrm{AF}$ wide using $0.32=1$ foot; obviously, the unit used was the Roman, not the Byzantine, foot and it is confirmed by other measurements in the building. With very few exceptions, once the correct unit of measurement is determined and applied to the diameters of the buildings octagon or inner and outer octagons, the resulting calculation is a round number divisible by ten.

It should be noted that most buildings were not laid out and constructed to exact measurements; a few were but more often than not 
the measurement is off by a few centimeters. Therefore, for example, it might be determined that the actual measurement of a diameter might be 29.8 or 30.3 feet, but the intended measurement was clearly 30 feet. This lack of precision is well known in Roman architecture, as scholars have noted ${ }^{6}$.

In my study of the octagonal churches of Late Antiquity it was obvious that most scholars had not considered the basic original measurements used in their layout and in the planning of their domes. One of the earliest monumental octagonal martyria is that dedicated to St. Philip at Hierapolis (Pammukale), Turkey, constructed at the end of the fourth or early in the fifth century ${ }^{7}$. Designed with an octagonal core defined by eight angle piers set within a second octagon containing spaces opening off of each of the inner octagons sides, as well as filler rooms, the whole was encased within a square outer block with small rectangular rooms facing the exterior and four entrance halls into the church (fig. 1).

The planning and layout of the building would have begun with locating the center of the building and drawing a circle around it. From one inner pier angle to its opposite is $22.45 \mathrm{~m}$ according to Verzone, which translates to 75 Roman feet at $0.2995 \mathrm{~m}=1$ foot, or 50 cubits $^{8}$. However, it is more likely that the builder was concerned with more than the span of the interior space and that his "critical measurement" for the first circle in laying out the central octagon would have included an accommodation of the drum wall intended to rise above the eight central piers to hold its wood dome. Therefore, his circle was drawn at 80 Roman feet, marking the center of the piers rather than their inner or back faces. Another measurement that confirms this hypothesis is that of the outer octagon, which is inscribed within a circle measuring $48.20 \mathrm{~m}$, equal to 160 Roman feet. Thus, the simplicity of the design is revealed: two octagons, the outer one having a measurement that is twice the diameter of the inner one in a basic 2:1 proportional scheme.

6. M. W. Jones, Principles of Roman architecture, p. 71 sq.; R. Taylor, Roman builders, p. 66-75.

7. This and all other buildings mentioned here are discussed in my book (M. J. Johnson, San Vitale in Ravenna and octagonal churches in Late Antiquity) where complete references may be found.

8. P. Verzone, "Il martyrium ottagono a Hierapolis di Frigia”, p. 10. 
Fig. 1 - Martyrium of St. Philip, Hierapolis, plan with circles demonstrating the layout of its two octagons. 
Fig. 2 - St. George, Izraa, plan with circles demonstrating the layout of its two octagons.

The church of St. George at Izraa in southern Syria is the only octagonal church still standing in addition to Sts. Sergius and Bacchus and San Vitale 9 . A dedicatory inscription above its central western door gives a date of 515. In plan, the church has a central octagon defined by angle piers, surrounded by an ambulatory on seven sides, set out as an octagon encased within a square block (fig. 2). A chancel and apse project out from the eastern side. The building was constructed using a Roman foot equal to $0.2995 \mathrm{~m}$. The piers forming the inner octagon were set within a circle measuring about $12 \mathrm{~m}$ or 40 Roman feet in diameter. The outer octagon forming the ambulatory measures just under $18 \mathrm{~m}$ or 60 Roman feet in diameter, measured from the interior corners. This demonstrates the use of another simple proportional scheme, in this case 3:2.

9. L. Saybaa, "The historical church of Saint George in Izraa, Hauran, Syria”. 
Fig. 3 - Sts. Sergius and Bacchus, Constantinople (Istanbul), exterior from northeast.

The piers inside the church rise to a height of about $4.5 \mathrm{~m}$ or 15 Roman feet, supporting arches that in turn carry a drum wall. The upper part of the drum wall and the dome have been reworked several times, so it is now impossible to determine the original height of either, and therefore, to draw any conclusions about the proportions used in its original interior elevation.

Justinian and his wife Theodora built the church of Sts. Sergius and Bacchus in Constantinople on the grounds of the Hormisdas Palace, located near the sea, south of the city's hippodrome (fig. 3). It was constructed next to another ecclesiastical foundation of Justinian, the church of Sts. Peter and Paul, sharing a porch or narthex with it. The palace was the official residence of the couple from 518, when his uncle Justin became emperor, until Justinian ascended the throne in August 527 at his uncle's death and moved with his wife into the nearby Great Palace. Perhaps because of his patronage of these new churches, Justinian then had the walls of the Great Palace extended to include the Hormisdas Palace.

The dedicatory inscription inside the church refers to Justinian as emperor, which he became in 527. Most scholars have seen this as a starting point in the construction of the church, meaning it was begun 
Fig. 4 - Sts. Sergius and Bacchus, Istanbul, plan with circles demonstrating the layout of its two octagons.

after he and Theodora left the Hormisdas palace. Brian Croke however, has pointed out that the inscription would not have been carved before the blocks were put in place, but after, as the church was nearing completion. It seems more likely that the project would have been begun at a time when Justinian and Theodora still lived in the Hormisdas, perhaps when Justinian was given the title of Caesar in $525^{10}$. It is also possible that the church was planned even earlier, before Justinian received an imperial office, but then begun only in the middle of the decade, and completed in late 527 or shortly afterwards after Justinian had ascended the throne.

Io. B. Croke, "Justinian, Theodora and the church of Saints Sergius and Bacchus", p. $47 \mathrm{sq}$., who also gives a translation of the inscription. 
Although freestanding and isolated in its present condition, the church was built as an integral part of the Hormisdas complex, as witnessed by the openings, now walled in, on its south and north flanks on both levels. To the south of the church stood the church of Sts. Peter and Paul. To the north, now an open area planted with a lawn, was some part of the palace proper, meaning people could move between the palace and the two churches without exiting.

The plan of the church consists of an octagonal core set within an irregular square or trapezoid, its size and shape determined in good part by the pre-existing church to the south, the location of the other church's narthex, which was extended to the north, and by the palace on the north side (fig. 4). This outer block measures $26.54 \mathrm{~m}$ on its north side, $27.4 \mathrm{~m}$ wide on its west side, and $25.77 \mathrm{~m}$ on its east side. Inside, eight polygonal piers surround the naos (nave) of the church creating a slightly oblong octagon with an interior width from north to south of $15.40 \mathrm{~m}$, and a slightly longer length, $15.75 \mathrm{~m}$, from east to west. The inner diameter of the space, measured from corner to corner, varies between 16.56 to $17.71 \mathrm{~m}$. The openings between columns on the north, west and south have straight columnar screens of two columns each. Those of the diagonals have curved columnar exedrae, again with two columns each.

The central octagon has an axis that is slightly different from that of its surrounding enclosure. On the east side the axis of the octagon continues straight through the sanctuary and apse. The sharp angle of the east wall of the church so noticeable on the plan is actually laid out so that the wall is at $90^{\circ}$ to the octagon's axis. The west wall and narthex, on the other hand, are at a different angle, and are at a right angle to the south wall of the church, which was the north wall of the church of Sts. Peter and Paul.

Scholars have had difficulty determining the metrology of the building and the measurement for the foot used by the architect in designing and constructing the church has been subject to different interpretations. Atilla Arpat took the north-south width of the central octagon of $15.40 \mathrm{~m}$, assumed it was based on a round number, so divided that number by 50 to yield a standard in which 1 foot equals $0.308 \mathrm{~m}^{11}$.

II. A. Arpat, "Jesus Christus und die Zahl 12 in den Dimensionen der SergiosBakchos Kirche zu Istanbul”, p. 35. 
Paul Underwood also assumed that the span of the octagon was laid out at 50 feet, but used the east-west measurement of $15.75 \mathrm{~m}$ to calculate a foot equal to $0.315 \mathrm{~m}^{12}$. More recently, Helge Svenshon expressed some doubt about being able to determine the unit used here, but suggested that perhaps 1 foot $=0.3133 \mathrm{~m}$, the value used in the construction of Hagia Sophia, which makes the interior width 49 feet instead of $50^{13}$. The problem with all three is that none seem able to explain the other measurements used within the structure.

As it turns out, many measurements in the building seem to be based on a foot that is $0.32 \mathrm{~m}$ in length. Dimensions in the plan that seem to be based on a foot of this length include the length of the exterior of the east wall, $25.77 \mathrm{~m}$ or $80 \mathrm{BF}$, the width of the narthex at $4.49 \mathrm{~m}$ or $14 \mathrm{BF}$, the width of the corner niches at $3.20 \mathrm{~m}$ or $10 \mathrm{BF}$, and the center doorway is $2.77 \mathrm{~m}$ or $82 / 3 \mathrm{BF}$ wide. The chord of the apse is $6.70 \mathrm{~m}$ or $21 \mathrm{BF}$ wide and the sanctuary's dimensions are $7.70 \mathrm{x} 3.75 \mathrm{~m}$ or $24 \mathrm{x}$ $12 \mathrm{BF}$. The exterior walls are $0.95 \mathrm{~m}$ or $3 \mathrm{BF}$ thick.

The most important part of laying out the church as construction began between the two pre-existing structures was placing the eight piers that would form its core and carry the dome. Although most scholars have assumed that the diameter of the irregularly shaped dome was designed on the idea of it being $50 \mathrm{BF}$, this is not the correct assessment of the dome's size and the planning that went into its design and construction. The key measurement for the builder was the maximum span that would need to be covered, which is determined by the distance between opposite interior corners of the diagonals of the octagon plus the thickness of the dome or its drum. The measurements between piers, as noted, vary between $16.56 \mathrm{~m}$ and $17.71 \mathrm{~m}$ with an average span of $17.16 \mathrm{~m}$, or about $54 \mathrm{BF}$, based on a foot of $0.32 \mathrm{~m}$. As it has been seen in the discussion of the other octagonal churches, domes normally are designed on the basis of a measurement divisible by 10. In this case, it can be assumed that the architect did the same thing, but made his critical measurement not based on the inner or outer faces of the piers' corners, but on the center of the piers. The piers are $1.90 \mathrm{~m}$ in length, or

I2. P. Underwood, "Some principles of measure in the architecture of the period of Justinian”, p. 66 sq.

I3. H. Svenshon, "Neue Überlegungen zum Grundrissentwurf der Sergios- und Bakchoskirche in Istanbul”, p. 125 sq. 
$6 \mathrm{BF}$, so measuring from the center of the pier adds $3 \mathrm{BF}$ on each end, yielding an average measurement of $19.06 \mathrm{~m}$ or $59.56 \mathrm{BF}$, showing that it was intended to be $60 \mathrm{BF}$, revealing the true critical measurement for the central core and its dome.

The most likely reason for the unusual plan seen here can be explained first by the fact that the pre-existing buildings on the north and the south determined the available width for the church and therefore the placement of its north and south walls, along with its western wall, as it shared the narthex with the early church to the south. The layout of the axis of the central octagon and the apse - the naos and sanctuary of the church - was determined on the day its orientation was determined, presumably as part of its foundation ceremony and irrespective of the orientation of the two earlier buildings.

There was room between the two buildings for a central core of octagonal naos and piers based on a 60 -foot diameter along the east-west axis, and desiring to maximize the building's size while using a round number as the critical measurement, it was set out as such. There was not enough space, however, to use this size for the central octagon and still have room for full ambulatories on the north and south, so the architect slightly narrowed the distance between of the northern and southern piers and rather dramatically narrowed the width of the ambulatories on those two sides.

Also, it is often overlooked that the church has two octagons, the outer one marked by the exterior wall of the ambulatory, obscured by the addition of the corner niches and the enclosing walls that give a somewhat square outer form to the church. Determining the placement of the exterior corners of the outer octagon allows one to explore the design relationship between the two octagons. The outer octagon, measured from corner to corner including the exterior walls is about $38.70 \mathrm{~m}$ or $120 \mathrm{BF}$. Therefore, the two critical measurements of the building are 120 and 60, translatable into a simple ratio of 2:1.

One gaping hole in the study of Late Antique and early Byzantine architecture is that of the use of proportions in the design of the vertical elements of a building ${ }^{14}$. It is of course logical to assume that the units of measurement employed in laying out a building would also use the

I4. One exception, though limited to fourth-century basilicas in Rome, is V. Hoffman, "Ein Einwurfsverfahren in der römischen Baukunst des 4. Jahrhunderts". 


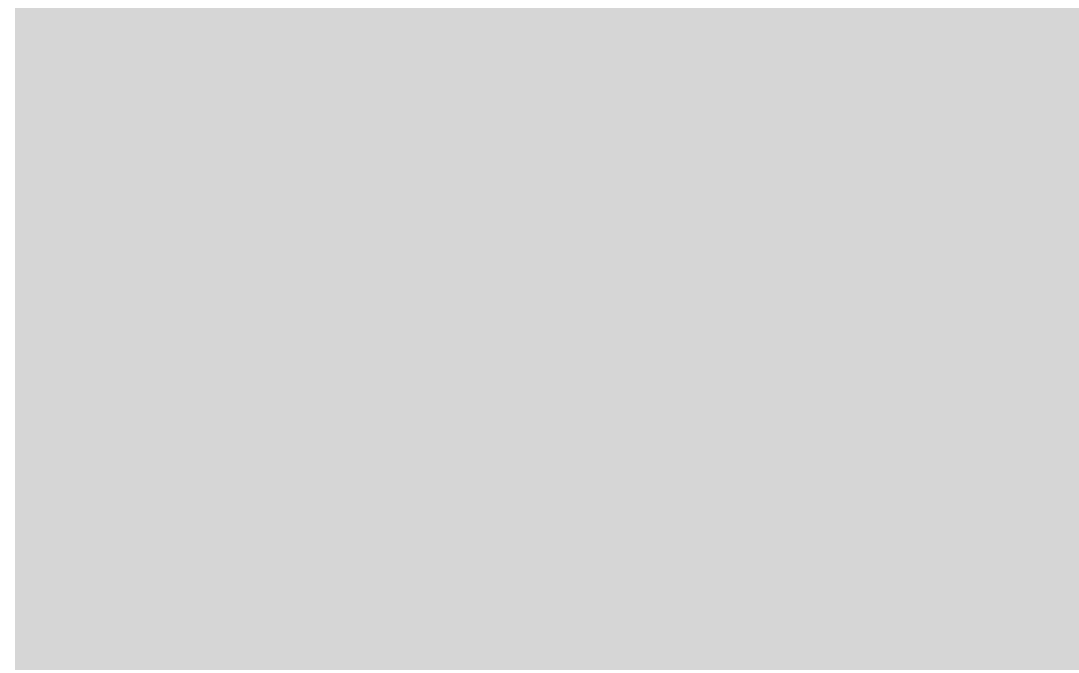

Fig. 5 - Sts. Sergius and Bacchus, Istanbul, section with measurements in feet.

same unit in planning and constructing its walls, openings and vaults, though no one has examined that until now. Furthermore, if simple proportional schemes were used in laying out elements of the plan, it follows that they would have also been used for the vertical components of the design.

These measurements and proportions are evident in the design of Sts. Sergius and Bacchus (fig. 5). The height of the ground floor order is $18 \mathrm{BF}$; that of the gallery order is $12 \mathrm{BF}$, with the two related to each other in a proportion of 3:2. From the floor to the top of the cornice of the gallery order is $32 \mathrm{BF}$. The height of the dome above the floor level is $66 \mathrm{BF}$, making it close to twice as high as the interior wall to the upper cornice in a 2:1 proportion. The height of the dome compared to the diameter of the circle used to place the piers is 1.1:1, slightly off the 1:1 proportional scheme used in the Pantheon. Two ratios used in the building are close to the golden ratio of 1.608:1. The height of the dome compared to the total height of the wall up to the springing point of the dome is $66: 42$, equal to $1.57: 1$. The height of the interior wall to the top

There are a few studies on proportions found in ground plans. See A. Papaconstantinou, "Divine or human?", with additional references. 
Fig. 6 - San Vitale, Ravenna, exterior from north.

of the cornice on the gallery level compared to the height between floors, $32: 20$, is equal to $1.6: 1$.

In 525 Ecclesius, bishop of Ravenna since 522, was part of a delegation led by Pope John I (523-526) to Constantinople, sent by the Ostrogothic king Theoderic (475-526) to negotiate with the Emperor Justin I (518-527) on his behalf. At some point after his return but before his death in 532, Ecclesius founded the church dedicated to Saint Vitalis. According to the legend, Vitalis was martyred during the reign of Marcus Aurelius. First tortured on a rack, he was then cast into a pit and covered with stones and dirt. A small chapel was built in the fifth century on the site of Vitalis' martyrdom and burial. This was razed to make way for Ecclesius' larger building, giving Ravenna its most important and most imposing martyr shrine (fig. 6) ${ }^{15}$.

The plan of the church is a double-shell octagon with an apse and flanking chambers on the east and an atrium on the west (fig. 7). At this point the axis of the church changes: there is not a door at the center

15. For an introduction to San Vitale, see D. Mauskopf-Deliyannis, Ravenna in Late Antiquity, p. 223-250; C. Jäggi, Ravenna - Kunst und Kultur einer spätantiken Residenzstadt, p. 238-259. 
Fig. 7 - San Vitale, Ravenna, plan with circles demonstrating the layout of its two octagons.

of the east wall of the narthex, but two doors, one to the north and one to the south that lead into the church. The center of the east wall of the narthex actually meets a corner of the outer octagon of the church rather than one of its sides as would normally be the case. This necessitated the adoption of transitional spaces between the narthex and the octagon of the church, here done as triangular rooms serving like inner narthexes. Each gave access to one of the two cylindrical stair towers leading to the gallery, though the southern one was later rebuilt and raised as a campanile. Entries into the church were more or less aligned to the doors connecting to the narthex and consisted of a triple opening with two columns supporting arches.

The octagonal core of the church, some $15.70 \mathrm{~m}$ wide, is defined by eight wedged-shaped piers that rise to support a drum and dome. Between each pier is an exedra, or curved space, defined by a pair of columns supporting arches and curving outwards away from the center of the building. On the east side, the piers are somewhat smaller and the exedra is eliminated in favor of a wider opening into the sanctuary. The core is enveloped by an ambulatory, which is encased within the octagon of the building's exterior wall. Each corner of the outer octagon is 
enlarged with buttresses, small on the interior and larger on the exterior, aligned to the piers of the interior core.

Virtually every scholar who has written about San Vitale has mentioned something about its connection to the church of Sts. Sergius and Bacchus. There are some similarities that everyone notes - the double shell design, the octagonal cores defined by eight piers with columnar exedrae between them, for example. Nevertheless, many are also quick to note the differences - Sts. Sergius and Bacchus is an octagon set within a square, the columns of its exedrae do not support arches but a flat lintel; it has a brick dome of the pumpkin type set directly above the crown of its arches with no intervening drum, and its interior space is not nearly as tall as that of San Vitale. The similarities are claimed to be based on nothing more than the trends present in architecture during the second quarter of the sixth century. Cyril Mango noted that the similarities between the two churches are obvious, but concluded that San Vitale "is not a derivative of (the church in Constantinople)" ${ }^{16}$. A close examination of the planning and design of San Vitale will show, however, that the connections between it and Sts. Sergius and Bacchus in the capital are much closer than previously imagined.

To start, no one, insofar as I can ascertain, has correctly identified the standard of measurement used in the design and construction of San Vitale before now. The Roman foot, equal to about $0.30 \mathrm{~m}$, was still being used in Ravenna during the first two or three decades of the sixth century, employed, for example, in the Mausoleum of Theoderic, built before the king's death in $526^{17}$. The standard of measurement used at San Vitale was the Byzantine foot, specifically, a foot equal to $0.32 \mathrm{~m}$, the identical measurement used at Sts. Sergius and Bacchus. This is demonstrated in several examples, from small to large. The bricks used in its construction measure $32 \times 48 \mathrm{~cm}$ were to the builders at the time bricks measuring $1 \times 1$ 1/2. feet. The narthex is $5.8 \mathrm{~m}$ or $18 \mathrm{BF}$ wide; the chords of its apses are $5.0 \mathrm{~m}$ wide or $16 \mathrm{BF}$ wide. The doors leading into the narthex from the atrium are $3.20 \mathrm{~m}$, or $10 \mathrm{BF}$, wide. Those from the narthex into the church are $3.8 \mathrm{~m}$, or $12 \mathrm{BF}$, wide. The cylindrical staircase is $7.0 \mathrm{~m}$, or $22 \mathrm{BF}$, in diameter. Inside the church proper, the piers are also $3.20 \mathrm{~m}$, or $10 \mathrm{BF}$, long. The opening into the sanctuary

I6. C. Mango, Byzantine architecture, p. 138.

I7. M. W. Jones, "Principles of design in Roman architecture", p. 147. 


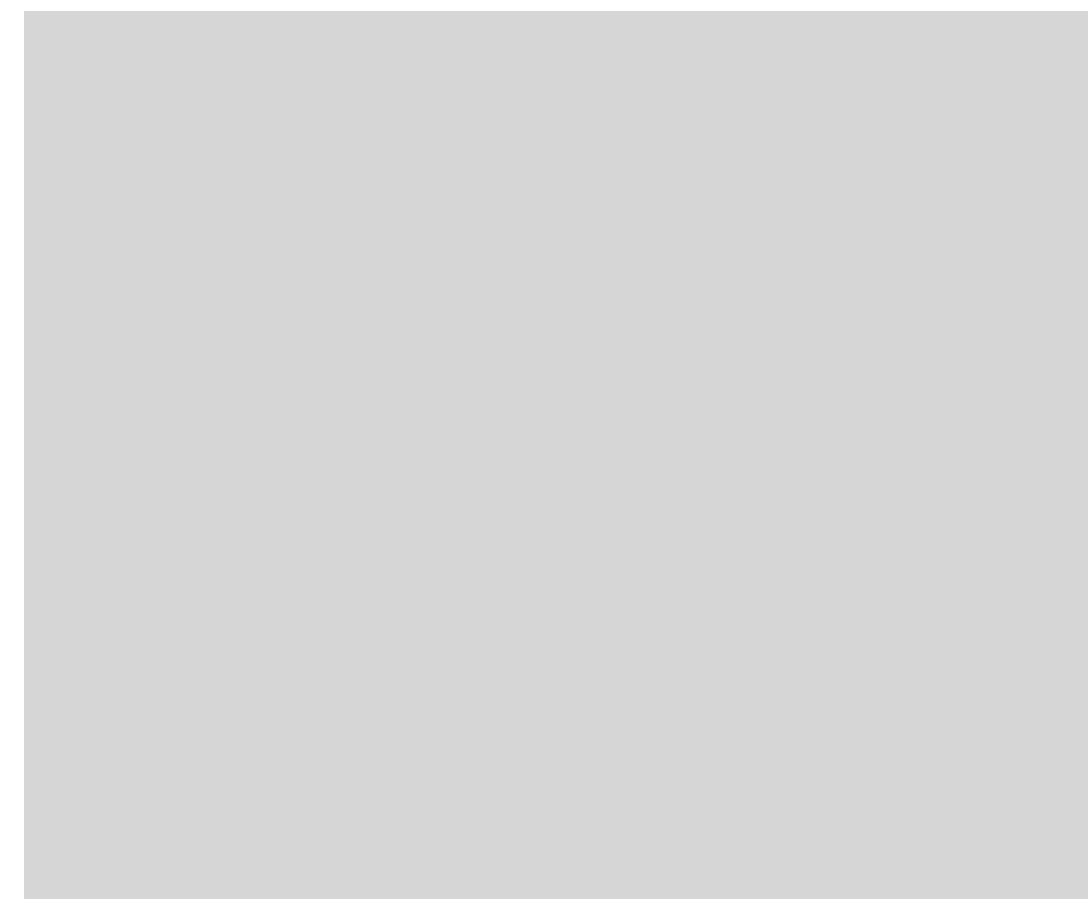

Fig. 8 - San Vitale, Ravenna, section with measurements in feet.

is $6.35 \mathrm{~m}$, or $20 \mathrm{BF}$, wide and the space is $10.1 \mathrm{~m}$, or $32 \mathrm{BF}$, long; the chord of the apse is $6.8 \mathrm{~m}$, or $21 \mathrm{BF}$, wide. The circular rooms flanking the sanctuary are $8.0 \mathrm{~m}$, or $25 \mathrm{BF}$, in diameter. Their western niches are $3.20 \mathrm{~m}$, or $10 \mathrm{BF}$, wide; their eastern niches $3.80 \mathrm{~m}$, or $12 \mathrm{BF}$, wide.

The layout of the two octagons demonstrates the use of this foot: the outer octagon, measured from corner to corner leaving off the exterior buttresses, that is the corner of the pure octagon, is about $38.60 \mathrm{~m}$, or slightly more than $120 \mathrm{BF}$. For the inner octagon, the critical measurement was not the width of the central space nor its interior diameter, but a point within the piers directly beneath the corners of the drum above, or $19.20 \mathrm{~m}$, exactly equal to $60 \mathrm{BF}$. The outer octagon was twice as large as the inner octagon in a simple 2:1 proportional scheme. These are the same dimensions of the "critical measurements", the two octagons at Sts. Sergius and Bacchus.

As in the church in Constantinople, the interior of the central space is domed and is enveloped by eight piers and columnar screens, here 
all curved exedrae on both the ground and gallery level (fig. 8). The exedra all support curved vaults, which add to the height of the space. Furthermore, at San Vitale a drum was inserted above the arches linking the piers, adding even more to the height. The planning of the interior elevation and its elements was done using the same unit of measurement seen in the plan. Once this is understood, it is simple to determine the simple ratios that guided the design.

Also, as at Sts. Sergius and Bacchus, the height of the ground floor order is $18 \mathrm{BF}$, but the height from the top of the order to the gallery floor has been increased by $8 \mathrm{BF}$ to a total of $28 \mathrm{BF}$. The height of the gallery order has also been raised, measuring here $14 \mathrm{BF}$, so that the total height from floor to the top of the gallery level order is $42 \mathrm{BF}$. This height compared to the height of the lower wall up to the gallery floor level, 42:28, yields a ratio of 3:2. The height of the lower wall up to the gallery level compared to the height of the gallery order was set out in a ratio of $2: 1$.

It is also noteworthy that at that same height of $42 \mathrm{BF}$ that the springing point of the dome of Sts. Sergius and Bacchus is found here, but here the vaults over the upper exedrae and the drum wall raise the height of the springing point to $65 \mathrm{BF}$, very close to the total height of the dome of the church in Constantinople. The height of the dome of San Vitale is $90 \mathrm{BF}$, making the ratio of height to diameter of the circle used to determine the layout of the piers 90:60, or 3:2. A simple ratio was used on the exterior of the church to determine the heights of the outer exterior wall, $50 \mathrm{BF}$ and of the drum, $30 \mathrm{BF}(5: 3)$.

Given the close ties between the two buildings and the evidence from the building itself, the following scenario for the construction of San Vitale seems likely. As noted in the discussion of Sts. Sergius and Bacchus, that church was not begun in 527 as some have argued, but sometime earlier. At the time of Ecclesius' visit to Constantinople in 525 it was well under construction. Impressed by what he saw and considering what to do to honor the martyr Vitalis in his own city, Ecclesius decided to construct a similar building of the same size. He may have taken a plan home with him and perhaps a written description; he may have even ordered a shipment of Proconessian marbles to be used in its construction. Back in Ravenna he likely conducted some sort of founding ceremony that could have taken place any time before his death in 532. Not much progress on the church seems to have been made 
during his lifetime and work stopped, perhaps initially with the death of Ecclesius, but also delayed due to the ongoing Gothic Wars.

The conquest of Ravenna on the part of the Byzantine army in 540 led to renewed efforts to complete the project initiated by Ecclesius. Julianus Argentarius, presumably a banker of eastern origin, is said in the dedicatory inscription to have provided the funds and ordered the bricks to be used, bricks that sized according to the new unit of measure that was now in use in Ravenna, the Byzantine foot. Bishop Victor (538565) gave his support and authority with a desire to complete the work begun by his predecessor.

Understanding the design of the building shows that whoever was in charge followed Byzantine practice. The diameters of the two octagons forming the body of the church matched those of its model in Constantinople. Was the architect or master builder overseeing this work a Byzantine or a local? The name of this person is not mentioned in the sources and there is a lot of a debate about this issue.

This is a question that cannot be settled definitively, but Richard Krautheimer is correct in stating that the architect/master builder did know exactly what was happening in architecture in the capital, and, one might add, he specifically knew and understood the design of Sts. Sergius and Bacchus ${ }^{18}$. At the same time, he made modifications, increasing the height of the building, setting out the building to align its main entrances with its main functional spaces, and adding chambers flanking the sanctuary on the east. Furthermore, the construction workers were likely locals and employed some local construction techniques such as using palafitti in the foundations and hollow tubes to construct the dome.

These are but a few examples but the use of critical measurements divisible by ten is found in almost all octagonal churches of Late Antiquity, following a tradition established in Roman architecture. The use of proportions based on simple ratios is found in both plans and elevations of these churches and also demonstrates a continuity of Roman architectural design. The design of domes in these churches is likewise based on this simple approach, whether in determining their diameter, or the height of their placement above the floor. Understanding the

I8. R. Krautheimer, Early Christian and Byzantine architecture, p. 236. 
underlying principles of design in these two buildings allows for the first time a more complete understanding of the close relationship they share.

Mark J. Johnson

Brigham Young University 


\section{BIBLIOGRAPHY}

Arpat, Atilla, "Jesus Christus und die Zahl 12 in den Dimensionen der Sergios-Bakchos Kirche zu Istanbul”, Ayasofya Muzesi Yilligi, 10 (1985), p. 34-40.

Croke, Brian, "Justinian, Theodora and the church of Saints Sergius and Bacchus", Dumbarton Oaks Papers, 60 (2006), p. 25-63.

Hoffmann, Volker, "Ein Einwurfsverfahren in der römischen Baukunst des 4. Jahrhunderts", Boreas, 26 (2002), p. 195-207.

JäGgI, Carola, Ravenna - Kunst und Kultur einer spätantiken Residenzstadt. Die Bauten und Mosaiken des 5. und 6. Jahrhunderts, Regensburg, Schnell+Steiner, 2013.

Johnson, Mark J., San Vitale in Ravenna and octagonal churches in Late Antiquity, Wiesbaden, Reichert Verlag, 2018.

Jones, Mark W., "Principles of design in Roman architecture: the setting out of centralised buildings", Papers of the British School at Rome, 57 (1989), p. 106-151.

-, Principles of Roman architecture, London, Yale University Press, 2000.

Krautheimer, Richard, Early Christian and Byzantine architecture, Harmondsworth, Penguin Books, 1986 (4th ed.).

Mango, Cyril, Byzantine architecture, New York, H.N. Abrams, 1976.

Mauskopf-Deliyannis, Deborah, Ravenna in Late Antiquity, Cambridge, Cambridge University Press, 2010.

Papaconstantinou, Arietta, "Divine or human? Some remarks on the design and layout of Late Antique basilicas", in Essays in Medieval art and archaeology in honour of Jean-Michel Spieser, ed. by Anthony Cutler, Arietta Papaconstantinou, Leiden, Brill, 2007, p. 31-46.

Rasch, Jürgen J., "Zur Konstruktion spätantiker Kuppeln vom 3. bis 6. Jahrhundert", Jahrbuch des Deutschen Archäologischen Instituts, 106 (1991), p. 311-383.

SaybaA, Loulou, "The historical church of Saint George in Izraa, Hauran, Syria", in Routes of faith in the Medieval Mediterranean. 
History, monuments, people, pilgrimage perspectives, ed. by Evangelia Hadjitryphonos, Thessaloniki, European Centre of Byzantine and Post-Byzantine Monuments, 2008, p. 372-379.

Shilbach, Erich, Byzantinische Metrologie, München, Beck, 1970.

Svenshon, Helge, "Neue Überlegungen zum Grundrissentwurf der

Sergios- und Bakchoskirche in Istanbul”, Architectura, 43 (2013), p. 113-128.

TAYlOR, Rabun, Roman builders. A study in architectural process, Cambridge, Cambridge University Press, 2003.

Underwood, Paul, "Some principles of measure in the architecture of the period of Justinian", Cahiers archéologiques, 3 (1948), p. 64-74.

Verzone, Paolo, "Il martyrium ottagono a Hierapolis di Frigia", Palladio, 10 (1960), p. 1-20.

\section{Credits}

Fig. 1: M. J. Johnson, redrawn after Krautheimer, Richard, Early Christian and Byzantine architecture, Harmondsworth, Penguin Books, 1986 (4th ed.), fig. 124.

Fig. 2: M. J. Johnson, redrawn after Butler, Howard Crosby, Early churches in Syria, fourth to seventh centuries, Princeton, Adolf M. Hakkert, 1929, p. 192.

Fig. 3 and 6: photo M. J. Johnson.

Fig. 4 and 5: M. J. Johnson, redrawn after SanPaOlesi, Piero, "La chiesa dei SS. Sergio e Bacco", Rivista dell'Istituto nazionale di archeologia e storia dell'arte, n.s. 10 (1961), 116-180, Tav. I and IV.

Fig. 7 and 8: M. J. Johnson, redrawn after Deichmann, Friedrich Wilhelm, Ravenna. Hauptstadt des spätantiken Abendlandes, II, Kommentar. Plananhang, Wiesbaden, F. Steiner, 1976, Plan 37 and 36 . 